International Journal of Instruction e-ISSN: 1308-1470 • www.e-iji.net

Article submission code: 20200119092337

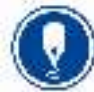

Received: $19 / 01 / 2020$ Revision: 29/08/2020
April 2021 • Vol.14, No.2

p-ISSN: 1694-609X

pp. $103-116$

Accepted: 21/09/2020

OnlineFirst: 11/01/2021

\title{
Beliefs about Intercultural Communicative Competence: The Development and Validation of a New Instrument
}

\section{Zerde Duisembekova}

Dr., English Philology and Translation Department, Khoja Akhmet Yassawi International Kazakh-Turkish University, Kazakhstan, zerde.duisembekova@ayu.edu.kz

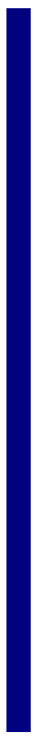

The present paper describes the development and validation of a new instrument designed to explore English language teaching (ELT) student teachers' beliefs about Intercultural Communicative Competence (ICC) in an expanding-circle context, Turkey. The process of instrument development and validation is described along with a concise literature review of ICC. Forty-eight items were prepared based on a comprehensive review of literature. 34-item instrument was developed following two phases: First, an exploratory factor analysis of the responses of a large sample $(\mathrm{N}=399)$ of ELT student teachers, and then a subsequent confirmatory factor analysis with another large but different sample $(\mathrm{N}=378)$ were performed. The Kaiser-Meyer Olkin (KMO) coefficient was found as 0.90 and the Bartlett test result (Chi- Square 3613.58; $\mathrm{p}<0.01$ ) was found significant. The results of the analysis indicated that the inventory has a perfect reliability value with .925 , resulting in 34 items. The four factors that emerged from the exploratory factor analysis are attitudes, knowledge, awareness and skills. The result of confirmatory factor analysis indicated that GFI $=0.93$, AGFI $=0.73$, $\mathrm{CFI}=0.77, \mathrm{NNFI}=0.93, \mathrm{RMSEA}(90 \% \mathrm{CI})=0.076(0.041-0.086)$ and SRMR $=$ 0.046. Based on these findings, the study provides suggestions with regard to the potential uses of the Beliefs about Intercultural Communicative Competence Inventory (BICCI) in second language teacher education.

Keywords: ICC, English student teachers, teaching beliefs, validity, reliability

\section{INTRODUCTION}

One of the greatest demands of our time from the individual is the ability to communicate across borders and cultures. In this regard, incorporating an intercultural teaching perspective in foreign language education stands for a solid necessity that has emerged over the last few decades. In the early 1990s, Byram (1997) expressed the idea that native speakers cannot be a model, since language learner is forced to abandon a language to merge with another linguistic environment, becoming a 'linguistic schizophrenic' (p.398). Moreover, he questions the need for a detailed acquaintance with the culture of the country of the language being studied, especially, when this language

Citation: Duisembekova, Z. (2021). Beliefs about Intercultural Communicative Competence: The Development and Validation of a New Instrument. International Journal of Instruction, 14(2), 103116. https://doi.org/10.29333/iji.2021.1427a 
is English. This questioning is grounded on the fact that most of the English speakers across the globe are non-natives. Therefore, for communication, it is necessary to have an idea of the culturally different countries and people and to cultivate a tolerant attitude towards all cultures (Byram, 2008). We must not forget that teaching foreign languages does not consist simple transfer of reading, speaking, and writing and listening skills, but rather it implies expanding worldview, providing opportunities for real-life experiences to empathize with other cultures.

In this regard, Bayram and Zarate (1994) proposed to replace the native speaker model with the model of the 'intercultural speaker' (p.156). At first glance, the intercultural speaker seems less competent than a native speaker does, but, at the same time, it has many advantages in communicating with native speakers of other languages and cultures. Common European Framework of Reference for Languages: Learning, Teaching, Assessment (CEFR) (CoE, 2001) has an ambitious objective which declares that the purpose of teaching modern languages is to promote 'mutual understanding and tolerance, respect for identities and cultural diversity through more effective international communication' (p.3). Therefore, some scholars in the field of intercultural competence and foreign language education suggest integrating ICC in a languagelearning program to promote learners with intercultural knowledge and skills (Alptekin, 2002; Byram, 1997; Crystal, 2003; Corbett, 2003). Besides, Ho (2009) pointed out that the development of ICC among language learners is a need to overcome cultural barriers while interacting with people from other cultural backgrounds. Hence, the CEFR led the way in promoting interculturally informed foreign language education (FLE) as a means for cultivating intercultural skill, knowledge, attitude, and awareness including tolerance, pluralism, and social justice (CoE, 2001).

While the role of second language teacher education (SLTE) in fostering ICC is well established in other contexts, notably in Europe, it is still a concern in Turkey's current SLTE programs. However, before implementing the ICC into ELT programs, it is crucial to identify the perceptions and beliefs of student teachers and teachers. Richardson (2003) pointed out that the beliefs of student teachers strongly affect what and how they learn and their future teaching approach in the classroom. Beliefs, in general, are defined as "psychologically held understandings, premises, or propositions about the world that are felt to be true" (Richardson, 2003, p. 2). Fenstermacher (1979) argued that one of the key functions of teacher training programs is to ask prospective teachers to examine and evaluate their beliefs concerning classroom action. In general education (Pajares, 1992; Richardson, 2003) and language teacher education (Borg, 2003; Horwitz, 1987; Freeman, 2002; Özmen, 2012), there is a wide range of research that focused heavily on teacher and student teacher beliefs. Moreover, the literature shows that there is a comprehensive research body which identifies students' and teachers' perceptions or attitudes towards ICC. To date, although teachers' beliefs on ICC (Castro, Sercu, \& Garcia, 2004; Young \& Sachdev, 2011) have been examined, small consideration has been made towards ELT student teachers' beliefs about ICC in EFL contexts, particularly in expanding circles (Czura, 2016), from the perspective of intercultural awareness, knowledge, attitudes and skills. 
Byram and Risager (1999) would be one of the earliest ICC researchers who explored teacher views about integrating culture into their English language classes. They conducted questionnaires and interviews with teachers in Denmark and the UK. The results indicated that very few teachers think that cultural dimension is more important than linguistic one in language teaching. However, the findings revealed that participants were willing to teach both culture and language and aware of significance of the cultural dimension.

Sercu and his colleagues (2005) developed an instrument called "Foreign Language Teachers and Intercultural Competence Questionnaire" that examines foreign language teachers' beliefs about intercultural competence. The instrument contained 11 sections. The average time required to complete the survey was about one hour. The participants of the research were teachers from Belgium, Sweden, Poland, Spain, Bulgaria, Greece, and Mexico. The results showed that the beliefs of teachers about teaching and learning affected their interpretations of particular teaching circumstances and consequently their teaching practice. The findings also suggested that participants were reluctant to integrate ICC into foreign language education and believed that culture and language could be taught in an integrated way.

Although the "Foreign Language Teachers and Intercultural Competence Questionnaire" (FLTICQ) has been determined as a valid and reliable tool for investigating the beliefs of foreign language teachers about Intercultural Competence (Sercu et al., 2005), it does not measure ELT student teachers' beliefs. This measure was developed to investigate in-service teachers, not pre-service teachers. Many studies have adopted and modified this instrument to measure student teachers' beliefs of ICC; however, the statements do not involve student teachers in evaluating ICC beliefs. Although the FLTICQ was a useful instrument in its time, the current dynamics of second language teacher education require a new instrument to cater for the constantly changing nature of teacher education.

Moreover, Hammer and Bennett (1998) designed an Intercultural Development Inventory (IDI) to assess intercultural sensitivity, which includes seven subscales. The inventory consisted of 50 items and based on the Bennet's (1993) DMIS model (Developmental Model of Intercultural Sensitivity). The instrument has proved its validity and reliability (Zhang, 2014). However, this scale is used in intercultural communication training for the business area because Bennett's (1993) DMIS does not have the academic consequences for teaching foreign languages, while Byram's model works for the EFL contexts. Fantini (2007) developed and validated the Assessment of Intercultural Competence (AIC), a scale that measures four constructs of intercultural competence: knowledge, skill, attitude, and awareness; however, these constructs are not defined under Byram's (1997) intercultural competence model.

It has been widely argued that the beliefs of language teachers about ICC could have a powerful influence on learners' ICC development (Sercu et al., 2005). Thus, investigating the impact of student teachers' beliefs on their future careers is crucial for teacher educators. Although various scholars have tried to improve ICC in admirable ways, very few attempts have involved the student teachers' ICC beliefs. Czura (2016) 
used an instrument (developed by Sercu et al., 2005) in her study to unearth the student teachers' views on ICC in a Polish context. The original instrument was intended for foreign language teachers, several changes have been made to adopt it. The study underlined that there was an urgent need to revise the teacher education objectives with aspects of ICC teaching.

Some research studies related to Turkish student teachers and teachers' beliefs were also carried out. For instance, Kılıç (2013) designed a scale to explore the beliefs of 368 English lecturers about intercultural competence. The participants of the study do not agree that studying culture is one of the primary goals of teaching the English language and they believe more in the attitudinal aspect of teaching culture. Besides, the study suggested that methods for measuring and evaluating English language teaching should be adopted to evaluate intercultural competence. In the same context, Güven (2015) developed a questionnaire, which examined the attitudes of 508 EFL students towards ICC. The participants were students of a preparatory school in Turkey. The findings yielded that participants generally had positive attitudes towards culture. Likewise, Atay et al. (2009) studied the attitudes of 503 language teachers towards intercultural teaching by using Sercu's et al. (2005) questionnaire. The results obtained revealed that teachers were highly interested in teaching culture in foreign language education.

Given the studies presented above as well as the researchers' observations, the relevant research studies mostly employed foreign language instructors or in-service teachers as the target population as observed in Turkey and other contexts. Therefore, there is little information about ELT student teachers' ICC beliefs in Turkey. Besides, the previous instruments (Sercu et al. 2005) that attempted to unveil the perception of ICC have had some shortcomings. These instruments are used to reveal the teachers' perception of ICC, not the students' or learners' perceptions or beliefs. Therefore, developing a valid and reliable instrument to shed light on student teachers' beliefs about ICC is a significant step in the development of an ELT curriculum for pre-service teacher education. To this end, the present study intended to construct the questionnaire item, collect data and analyze it to create a valid and reliable tool. Beliefs about Intercultural Communicative Competence Inventory (BICCI) is designed for the researchers and teacher educators to examine the beliefs of student teachers about ICC. This study also attempted to serve as an evaluation tool that can be used by student teachers to identify their own ICC belief in pre-service teacher education.

\section{Defining the Construct}

In the present research design, a survey developed by the researchers on the ICC beliefs of ELT student teachers was used to collect quantitative data. Specifically, four components of ICC to be measured are attitudes, knowledge, awareness and skills as defined by Byram (1997). The questionnaire items were developed based on the theoretical model of ICC, a construct that refers to being able to communicate with the people of different cultures (Byram, 1997, Deardorff, 2006; Fantini, 2009). For constructing the BICCI, the researchers utilized Byram's (1997) model of ICC. Byram defined ICC in terms of five abilities (savoirs): the first one is savoir-être, which means attitudes and values, and the second one is savoirs, which stands for knowledge. The 
third one is savoir-apprendre, which represents ability to learn. The fourth one is, savoir-faire, which means knowing how, and fifth one is savoir s'engager, which represents ability to evaluate.

Regarding attitude, which is one of the core aspects of intercultural communication, it refers to the individuals' curiosity, openness towards other cultures and readiness to see other cultures and one's own culture without judgment (Byram, 1997). Knowledge addresses the individual's knowledge of the target and one's own country's social groups, products, practices, and the general processes of social and individual interaction (Byram, 1997). The component 'skill' concerns the individual's ability to interpret a document or event from another culture. Finally, awareness is about challenging preconceived ideas toward different cultures and identifying cultural values in documents and events, questioning information obtained about different cultures, and interacting and mediating in intercultural exchanges (Byram, 1997).

\section{METHOD}

\section{Participants}

The inventory was administered to ELT student teachers in several universities located in various cities across Turkey. The data of study included a total of 777 student teachers divided into two groups. The first group took role in the initial phase of development of the BICCI factor structure, consisted 399 participants. The second group was investigated to validate the measurement model. The student teachers' ages ranged from 20 to 38 years $(M=22.50)$. The convenience sample approach was employed to select the respondents. The sample size for the participants was more than the acceptable threshold for factor analysis, which was equal to 350 (Hair et al., 2010).

\section{Instrument Development}

Following standard criteria for the development of valid and reliable questionnaires (Dörnyei, 2003), we began by examining the relevant literature on ICC. We analyzed the existing instruments designed to examine the student teachers' beliefs about ICC. At the beginning, the factors were identified. After setting the factors, items were written for each of the factors. The item pool for all factors consisted of approximately 180 items. Among these items, an expert opinion form consisting of 41 items were created in order to check its content validity. The expert's opinions were expected to define either appropriate or inappropriate for each item. After their feedback, necessary revisions about the language, factors, grading and label were made and several items were reworded to offer more comprehensible items. A pilot study was carried out at Ataturk University, Gazi University, and Pamukkale University with 399 student teachers enrolled in ELT programs. Then, an inventory form consisting of 41 items was created. The format of the inventory was designed in accordance with the guidelines outlined by Brown (2001) and Dörnyei (2003). A 5-point Likert scale ranging from "strongly agree" to "strongly disagree" was chosen to measure the student teachers' beliefs.

\section{Data Collection and Analysis}

Exploratory Factor Analysis (EFA) and Confirmatory Factor Analysis (CFA) were used to establish the extent of the validity and reliability of the instrument. For the 
development phase, the data gathered from 399 ELT student teachers were analyzed through SPSS 22. EFA was adopted for this phase. For the validation phase, the data gathered from 378 ELT student teachers underwent CFA and computed in LISREL 8.80 program for Windows.

\section{FINDINGS}

\section{Study 1: Exploratory Factor Analysis (EFA)}

The draft version of the BICCI was tested with the sample of $(\mathrm{N}=399)$ in various cities, in different learning contexts in Turkey. Of the total number of participants, $30 \%$ were male and $70 \%$ female. An investigation of the BICCI factor structure was conducted through SPSS (22). The pilot study helped the researchers to check the construct validity and the reliability of the questionnaire before finalizing the questionnaire. DeVellis (2003) defines construct validity as "the extent to which a measure "behaves" the way that the construct it purports to measure should behave with regard to established measures of other constructs" (p. 53). Factor analysis is aimed at determining "whether each item measured the subscale it was supposed to measure to look at construct validity" (Mujis, 2004, p. 70). 399 student teachers from three cities from different regions of the country filled in the questionnaire. The data were collected from student teachers on a paper-and-pencil format. The data were collected in two months and then factor analysis was carried out.

Before the factor analysis, the normality and the sample size were considered to determine whether sample data has been drawn from a normally distributed population. The Shapiro Wilk and Kolmogorov-Smirnov Tests for Normality were run to compare the scores in the sample to a normally distributed set of scores with the same mean and standard deviation (Can, 2017).

Table 1 shows that the results of both tests (Sig.) are bigger than $\mathrm{p}(0.05)$ value, which means that the normality of the test was ensured. In total, nine data were excluded after checking $\mathrm{Z}$ scores. Among the four factors identified before, there was no significant correlations, and thus Varimax Rotation was further run. In Correlation Matrix there was no value above the 0.80 . Determinant was higher than 0.001 .

Table 1

Tests of Normality

\begin{tabular}{lllllll}
\hline \multicolumn{3}{l}{ Kolmogrov-Smirnov } & \multicolumn{4}{l}{ Shapiro-Wilk } \\
\hline & Statistic & df & Sig. & Statistic & df & Sig. \\
\hline Total &, 043 & 352 &, 200 &, 964 & 352 &, 000 \\
\hline Zscore (total) &, 043 & 352 &, 200 &, 964 & 352 &, 000 \\
\hline
\end{tabular}

Kaiser-Meyer-Olkin (KMO) test was used to measure sampling adequacy and Bartlett's test of sphericity to measure the data's suitability for factor analysis. According to Tavşancıl (2005), it is essential that KMO value should exceed .60 and the Bartlett's test of Sphericity should have a significance of $p<.05$. As can be seen in Table 2, the KMO measure of sampling adequacy was .906 (>.60), suggesting that the sample size was adequate for the analysis. Besides, Bartlett's test of sphericity was significant at the .00 level $(\chi 2=5790.037, \mathrm{DF}=561, \mathrm{p}=.00)$, indicating the suitability of the data for factor analysis (Büyüköztürk, 2004). 
Table 2

The results of KMO and barlett's test of sphericity

\begin{tabular}{lll}
\hline KMO Measure of Sampling Adequacy & &, 906 \\
\hline Barlett's Test of Sphericity & Approx. Chi-Square & 5790,037 \\
\hline & df & 561 \\
\hline & Sig &, 000 \\
\hline
\end{tabular}

Total variance explained in the survey was $52.793 \%$. This value meant that the factors cumulatively explain $52.793 \%$ of the variance in the inventory. The acceptable value for total variance explained is about $50 \%$ which addresses the adequacy of this tool (Büyüköztürk, 2004; Tavşancıl, 2005).

Table 3

Total variance explained

\begin{tabular}{|c|c|c|c|c|c|c|}
\hline \multirow{2}{*}{ 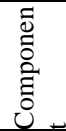 } & \multicolumn{3}{|c|}{ Initial Eigenvalues } & \multicolumn{3}{|c|}{ Rotation Sums of Squared Loadings } \\
\hline & Total & $\%$ of Variance & Cumulative \% & Total & $\%$ of Variance & Cumulative $\%$ \\
\hline 1 & 10,389 & 30,555 & 30,555 & 5,735 & 16,866 & 16,866 \\
\hline 2 & 3,065 & 9,013 & 39,568 & 5,395 & 15,869 & 32,735 \\
\hline 3 & 2,510 & 7,383 & 46,951 & 3,609 & 10,615 & 43,350 \\
\hline 4 & 1,986 & 5,842 & 52,793 & 3,210 & 9,443 & 52,793 \\
\hline 5 & 1,411 & 4,149 & 56,942 & & & \\
\hline 6 & 1,156 & 3,400 & 60,342 & & & \\
\hline
\end{tabular}

According to the results of the analysis, 14 items were excluded from the questionnaire and the number of items was reduced to 34 .

The scree plot was also examined to confirm the underlying factors as seen in Figure 1. The scree plot showed the existence of four factors after the breaking point.

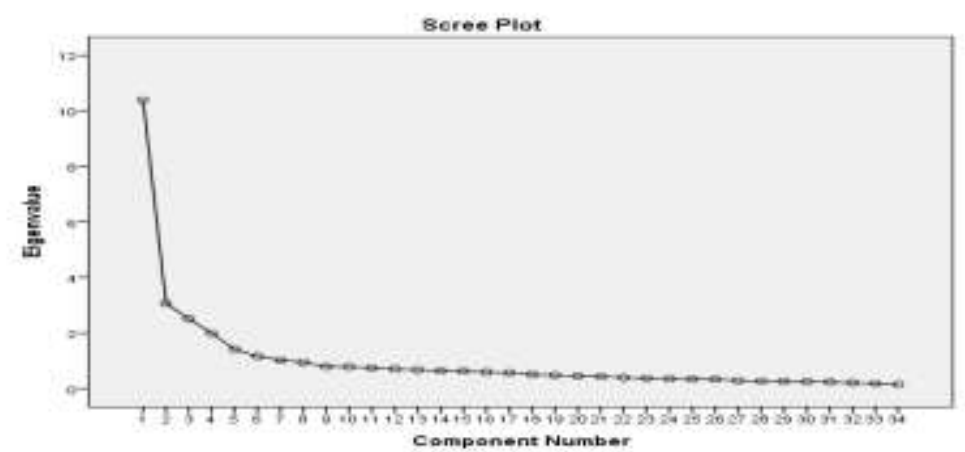

Figure 1

Scree plot

The rotated component Matrix (see Table 4 below) shows the items loadings on the four predetermined factors with 34 items loading above .10 on Component 1,8 items loading on Component 2, 6 items loading on Component 3 and 10 items on Component 4. A series of factor analyses were carried out through omitting low loaded items in order to determine the most optimal factor structure for the sub-scales. Finally, the results turned 
out four factors solution for each sub-scale. Regarding factor loadings, they ranged from .59 to .79 for the attitudes sub-scale, .48 to .81 for knowledge sub-scale, .49 to .75 for the awareness sub-scale and .47 to 88 for the skills sub-scale (Table 3 ).

Table 4

Factor analysis of the BICCI Items

\begin{tabular}{|c|c|c|c|}
\hline & $\stackrel{\Xi}{\Xi}$ & 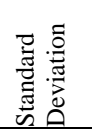 & 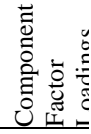 \\
\hline \multicolumn{4}{|l|}{ Attitudes } \\
\hline 1. I value cultural diversity. & 4,60 & ,56753 & ,641 \\
\hline 3. I respect people who have a different culture. & 4,72 & ,50947 & ,633 \\
\hline 4. I am open minded to foreigners who speak English. & 4,58 & 62309 & ,599 \\
\hline 5. I am curious about the culture of people from other countries. & 4,53 & ,62846 & ,658 \\
\hline 6. I am willing to learn from people who have different cultural orientations. & 4,44 & ,69729 & ,753 \\
\hline 7. I tolerate other cultures. & 4,45 & ,62287 & ,797 \\
\hline 8. I am willing to empathize with people who have different cultural backgrounds. & 4,11 & ,81021 & ,680 \\
\hline 9. I understand foreigners' worldviews. & 4,46 &, 59520 & ,739 \\
\hline 10. I understand the value of cultural diversity. & 4,32 & ,70637 & ,737 \\
\hline 13. I am flexible towards other cultures. & 4,37 & ,68362 & ,696 \\
\hline \multicolumn{4}{|l|}{ Knowledge } \\
\hline 21. I am well equipped with cultural patterns of the target language. & 3,00 & ,85104 & ,749 \\
\hline 22. I know the culture of people from other cultural backgrounds. & 2,93 & ,90202 & ,680 \\
\hline $\begin{array}{l}\text { 24. I know about the similarities and differences between the cultures of other } \\
\text { countries and Turkish culture. }\end{array}$ & 3,54 & ,79048 & 634 \\
\hline $\begin{array}{l}\text { 26. I know how people from different countries behave in various circumstances to } \\
\text { have a better communication with them. }\end{array}$ & 3,20 & ,92307 & ,580 \\
\hline 31. I know only the cultures of English-speaking countries. & 3,21 &, 81920 & ,528 \\
\hline 42. I can analyze the cultural information. & 3,74 & ,76272 & ,490 \\
\hline 43. I can interpret the cultural information. & 3,70 & ,76425 & ,507 \\
\hline 44. I can relate the cultural information. & 3,83 & ,70779 & ,542 \\
\hline \multicolumn{4}{|l|}{ Awareness } \\
\hline 11. I have a culture-specific knowledge of other countries. & 4,66 & ,54145 & ,537 \\
\hline 23. I understand my own cultural identity. & 4,25 & 66124 & 679 \\
\hline 27. I am aware of the cultural differences. & 4,36 & ,65976 &, 508 \\
\hline 28. I understand my own culture. & 4,47 &, 58595 &, 880 \\
\hline 29. I am aware of my own cultures. & 4,51 & ,56086 & ,859 \\
\hline 30. I am aware of the other cultures. & 4,16 & ,72217 & ,477 \\
\hline \multicolumn{4}{|l|}{ Skills } \\
\hline 32. I am able to communicate effectively with people from other cultures. & 3,85 & ,75137 & ,795 \\
\hline 33. I can communicate in socially appropriate ways. & 3,97 & 67204 & 810 \\
\hline 34. I can communicate in culturally appropriate ways. & 3,84 & ,73341 & ,782 \\
\hline 35. I am able to get information about the other cultures. & 4,10 & ,66338 & ,667 \\
\hline 36. I am able to communicate well verbally with people from other cultures. & 3,84 & ,72669 & ,767 \\
\hline $\begin{array}{l}\text { 38. I can identify some misunderstandings happening in interactions between Turkish } \\
\text { and English-speaking people. }\end{array}$ & 3,96 & ,72734 & ,611 \\
\hline $\begin{array}{l}\text { 39. I am able to contrast communicative behaviors of Turkish and English-speaking } \\
\text { people in social settings (e.g., family, school, office, etc.). }\end{array}$ & 3,91 & .71302 & ,612 \\
\hline $\begin{array}{l}\text { 40. I seek opportunities to explore the culture of target language communities out of } \\
\text { my programme (The Internet, forum, etc.). }\end{array}$ & 3,97 & ,79092 & ,486 \\
\hline 46. I can discover other cultures. & 4,10 & ,69583 & ,485 \\
\hline 48. I seek out opportunities to cooperate with individuals from other cultures. & 3,94 & ,79847 &, 483 \\
\hline
\end{tabular}


The items are gathered under the factors as in Table 5. This table shows the final factor analysis of "Beliefs about ICC Inventory". Based on the results of the analyses, 14 items were omitted from the inventory because of low factor loadings and reliability issues. As a result, the BICCI turned out a 34-item inventory with 10 items identified for the first factor, 8 items for the second factor, 6 items for the third factor, and 10 items for the fourth factor.

Table 5

Factor-Item distribution

\begin{tabular}{lll}
\hline Factors & Items & Items Number \\
\hline Attitudes & $1,2,3,4,5,6,7,8,9,10,13$ & 10 \\
\hline Knowledge & $21,22,24,26,31,42,43,44$ & 8 \\
\hline Awareness & $11,23,27,28,29,30$ & 6 \\
\hline Skills & $32,33,34,35,36,38,39,40,46,48$ & 10 \\
\hline
\end{tabular}

A reliable instrument for a piece of research will yield similar data from similar respondents over time. (Cohen, Manion \& Morrison, 2005). It is suggested that if the Cronbach's Alpha value is .70 or above, items shows reliability (Fraenkel et al., 2012). The internal consistency of the questionnaire was calculated using Cronbach's alpha coefficient, which is given in Table 6 .

Table 6

Reliability of the survey

\begin{tabular}{lll}
\hline Factors & Cronbach's Alpha & N of Items \\
\hline Attitudes &, 896 & 10 \\
\hline Knowledge &, 810 & 8 \\
\hline Awareness &, 783 & 6 \\
\hline Skills &, 890 & 10 \\
\hline Overall &, 925 & 34 \\
\hline
\end{tabular}

Cronbach's alpha for factor 1 was 0.896 , for Factor 2, it was 0.810, for Factor 3, 0.783 and for Factor 4, 0.890. Cronbach's alpha for the overall scale was 0.925. Based on the results of the analyses, 13 items were omitted from the inventory because of low factor loadings and reliability issues. After the pilot study and taking expert opinion on these results, all parts of the instrument were reconsidered and re-evaluated with the experts. The necessary revisions and reductions were made to better the quality of the questions and to increase the quality of the questionnaire for the main study.

\section{Study 2: Confirmatory Factor Analysis (CFA)}

The purpose of Study 2 was to assess the factor structure of the scores obtained from the 34- item questionnaire in Study 1, with an independent sample, via the confirmatory factor analysis (CFA). Study 2 reveals the findings from 378 student teachers' responses to 34-item inventory in order to validate the BICCI. We utilized CFA to test the stability of the four-factor 34-item BICCI using LISREL Version 8.80. The hypothesized fourfactor model was identified via EFA in Study 1.

The path diagrams of the model represented 34 continuous observed variables (factor indicators) displayed in Figure 2. The researchers executed second-order factor analysis 
in order to examine the correlations among the BICCI and the four sub-scales. The results revealed that there were high correlations among the BICCI and its subconstructs. The correlation between the BICCI and the attitude sub-scale was .57, the BICCI and knowledge sub-scale was .77, the BICCI and awareness sub-scale was .27 and the BICCI and skills sub-scale was .95 (Figure2).

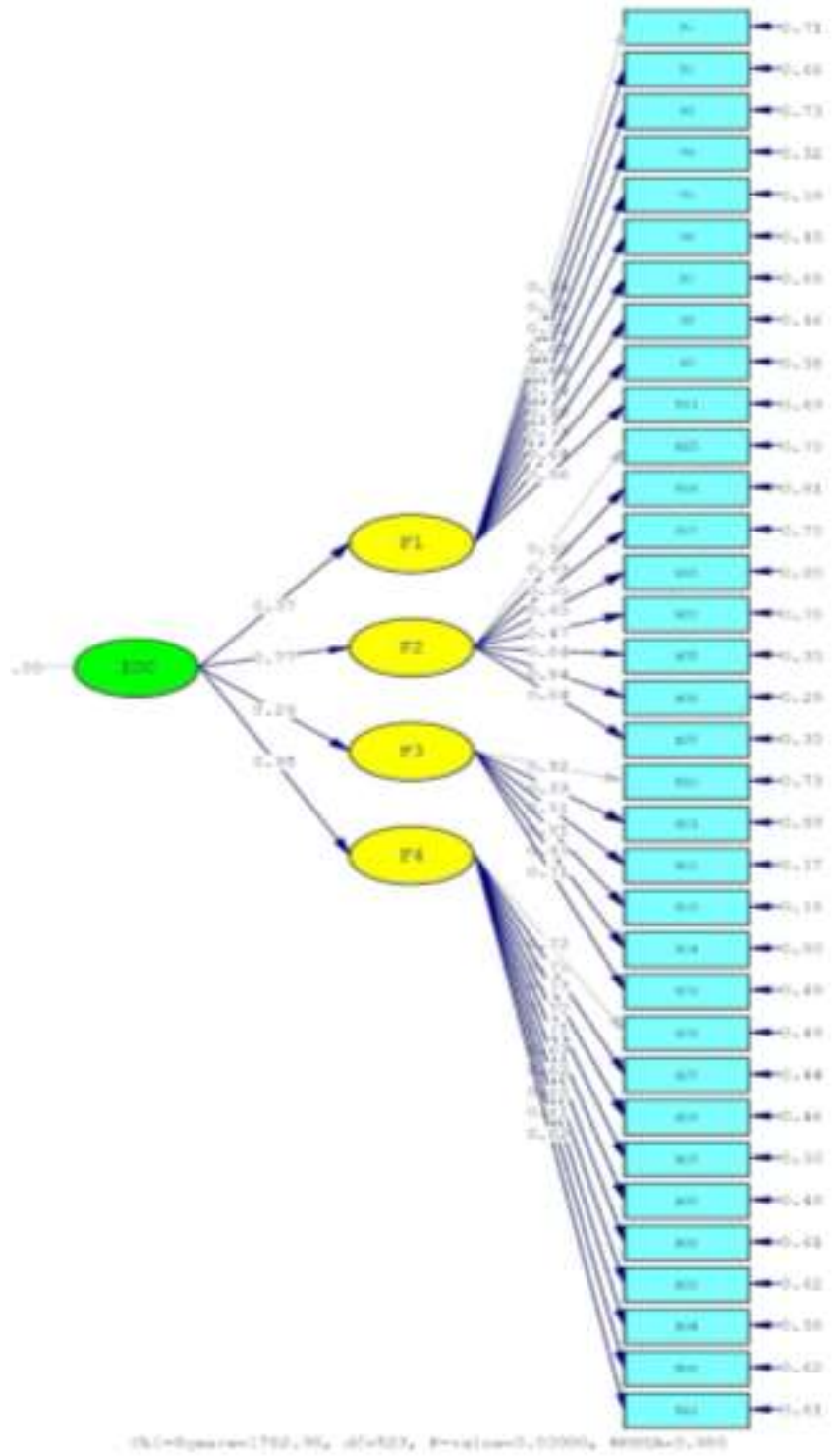

Figure 2

Standardized path 
Figure 2 presents the model of the BICCI factor structure. All the standardized path coefficients were statistically significant and salient (>.40).

Table 7 shows that the results of confirmatory factor analysis met the criteria of goodness of fit indices and the four-factor model fitted well which means that the BICCI has four factors in the Turkish University context. The fit indices $(\mathrm{CFI}=.93 ; \mathrm{RMSEA}=$ .08) suggested that the hypothesized model fit well.

Table 7

Fit indexes of confirmatory factor analysis

\begin{tabular}{llll}
\hline Fit Values & Good Fit Values & Acceptable Fit Values & ICC-Fit Values \\
\hline$\chi^{2}$ & $0 \leq \chi^{2} \leq 3 \mathrm{df}$ & $3 \mathrm{df}<\chi^{2} \leq 5 \mathrm{df}$ & 1782.90 \\
\hline $\mathrm{p}$ value & $0.05 \leq \mathrm{p} \leq 1.00$ & $0.01 \leq \mathrm{p} \leq 0.05$ & 0.000 \\
\hline$\chi^{2} / \mathrm{df}$ & $0 \leq \chi 2 / \mathrm{df} \leq 3$ & $3<\chi^{2} / \mathrm{df} \leq 5$ & 523 \\
\hline RMSEA & $0 \leq \mathrm{RMSEA} \leq 0.05$ & $0.05<\mathrm{RMSEA} \leq 0.08$ & 0.080 \\
\hline $\mathrm{SRMR}$ & $0 \leq \mathrm{SRMR} \leq 0.05$ & $0.05<\mathrm{SRMR} \leq 0.10$ & 0.100 \\
\hline $\mathrm{RMR}$ & $0 \leq \mathrm{RMR} \leq 0.05$ & $0.05<\mathrm{RMR} \leq 0.10$ & 0.055 \\
\hline $\mathrm{NFI}$ & $0.95 \leq \mathrm{NFI} \leq 1$ & $0.90<\mathrm{NFI}<0.95$ & 0.90 \\
\hline NNFI & $0.97 \leq \mathrm{NNFI} \leq 1$ & $0.95 \leq \mathrm{NNFI}<0.97$ & 0.93 \\
\hline CFI & $0.97 \leq \mathrm{CFI} \leq 1$ & $0.95 \leq \mathrm{CFI}<0.97$ & 0.93 \\
\hline GFI & $0.95 \leq \mathrm{GFI} \leq 1$ & $0.90 \leq \mathrm{GFI}<0.95$ & 0.77 \\
\hline AGFI & $0.90 \leq \mathrm{AGFI} \leq 1$ & $0.85 \leq \mathrm{AGFI}<0.90$ & 0.73 \\
\hline
\end{tabular}

\section{DISCUSSION AND CONCLUSION}

This study developed a valid and reliable inventory to unveil the ELT student teachers' beliefs about ICC. In the relevant literature, it is possible to come across several scales, which explore the perception of teachers about ICC. However, most of these instruments focused merely on in-service foreign language teachers rather than language learners or student teachers. Findings from EFA conducted in the first study $(N=399)$ indicated that the BICCI scores had four distinct factors that are labelled as Knowledge, Attitudes, Awareness and Skills. This four-factor structure of BICCI scores was confirmed via CFA in the second study $(N=378)$. The emergence of four factors is consistent with the current literature on ICC components (Byram, 1997).

The first factor in this study, namely "attitudes", conforms to the attitudes developed by Byram (1997) for his ICC model. This dimension concerns curiosity and openness, readiness to suspend disbeliefs about other cultures and beliefs about one's own culture (Byram, 1997). In a similar vein, Deardorff (2006), in her ICC framework, pointed out that people first needed to have positive attitudes such as openness and curiosity in order to welcome differences.

The items included in the second factor of the scale were related to cultural knowledge. "Knowledge" is related to getting information about the community culture and practices. It is essential for student teachers to have sufficient knowledge of different cultures. Byram (1997) asserted that a successful intercultural speaker should be able to distinguish between regional identities, regional dialects, and landmarks that are meaningful to native speakers. Deardorff (2006) suggested that people should have 
knowledge of ICC, which includes culture-specific knowledge, and deep cultural knowledge which may lead to understanding of other people's perspectives.

In the third factor of the scale, the items were related to cultural "awareness". It refers to an ability to evaluate - critically and based on explicit criteria - perspectives, practices and products in one's own and other cultures and countries. Chen and Starosta (1996) stated that the effective interculturalist possesses cultural self-awareness and cultural awareness, both of which help to reduce the ambiguity and uncertainty that are inherent in intercultural interaction. There are several studies about the significance of establishing cultural awareness in the literature (Brown, 2004; Milner, et.al. 2003).

Finally, for the last factor of the inventory, the items were related to intercultural "skills". This factor refers to the ability to acquire new knowledge of a culture and cultural practices and the ability to utilize knowledge, attitudes and skills under the constraints of real-time communication and interaction (Byram, 1997). In other words, people should have the skills that can promote ICC. Sercu (2006) emphasized that teachers should be able to help learners relate their own culture to foreign cultures, to compare cultures and to empathize with foreign cultures' points of view. Effective intercultural communicative competences have an important place in the professional and personal characteristics of a student teacher because foreign language learning and teaching, in general, is a communication process.

According to the results of this study, four factors (attitudes, knowledge, awareness and skills) were obtained from EFA results. The obtained four factors contributed to $52.793 \%$ of the total item variance in the ICC scale. All the four factors had quite higher Cronbach's alpha coefficient. Reliability coefficient which is equal or greater than .60 and less than $.90(0.60 \leq \alpha<0.90)$ it is assumed as quite excellent (Özdamar, 1999 as cited in Tavşanc1l, 2006). In conclusion, this study indicated that the new instrument possesses good reliability and validity estimates. Thus, the instrument can be utilized as a research tool to explore the ELT student teachers' beliefs about ICC in educational research area. We believe that this instrument will help preservice teacher education programs design and implement approaches that will encourage the development of ICC. In addition, use and modification of this instrument will encourage a line of research on analyzing beliefs of student teachers regarding intercultural competence.

\section{ACKNOWLEDGEMENTS}

We wish to express our gratitude to the many teacher educators who administered the questionnaire in their classrooms. We would also like to acknowledge and express our appreciation for the technical support of FatIma Nur Fişne, a research assistant of ELT Program at Gazi University.

\section{REFERENCES}

Alptekin, C. (2002). Towards intercultural communicative competence in ELT. ELT Journal, 56(1), 57-64. 
Atay, D., Kurt, G., Çamlıbel, Z., Ersin, P., \& Kaşlığlu, O. (2009). The role of intercultural competence in foreign language teaching. Inonu University Journal of the Faculty of Education, 10(3), 123-135.

Bennett, M. J. (1993). Towards ethnorelativism: A developmental model of intercultural sensitivity. In R. M. Paige (Ed.), Education for the intercultural experience (pp. 21- 71). Yarmouth, ME: Intercultural Press.

Brown, J. D. (2001). Using surveys in language programs. Cambridge.

Brown, E. (2004). What precipitates change in cultural diversity awareness during a multicultural course: The message or the method? Journal of Teacher Education, 55, 325-340.

Borg, S. (2003). Teacher cognition in language teaching: A review of research on what language teachers think, know, believe, and do. Language teaching, 36(2), 81-109.

Büyüköztürk, Ş., Çokluk, Ö., Şekercioğlu, G. (2004). Sosyal Bilimler için Çok Değişkenli Istatistik SPSS ve LISREL Uygulamaları. Ankara: Pegem Akademi.

Byram, M. (1997) Teaching and assessing intercultural communicative competence. Clevedon, Multilingual Matters.

Byram, M. \& Zarate, G. (1994). Definitions, objectives and assessment of socio-cultural competence. Strasbourg: Council of Europe.

Byram, M. (2008). From foreign language education to education for intercultural citizenship: Essays and reflections. Clevedon: Multilingual Matters.

Can, A. (2017) SPSS ile Bilimsel Araştırma Sürecinde Nice Veri Analizi. Pegem Akademi.

Castro, P., Sercu, L. \& Garcia, M. C. M. (2004). Integrating language-and-culture teaching: an investigation of Spanish teachers' perceptions of the objectives of foreign language education. Intercultural Education, 15(1), 91-104.

Chen, G. M. \& Starosta, W. J. (1996) Intercultural communicative competence: a synthesis, Communication Yearbook, 19, 353-383.

Cohen, L., Manion, L., \& Morrison, K. (2005). Research methods in education (5th ed.). Routledge.

Corbett, J. (2003). An intercultural approach to English language teaching (Vol. 7). Multilingual matters.

Deardorff, D.K. (2006). Identification and assessment of intercultural competence as a student outcome of internationalization. Journal of Studies in International Education, $10(3), 241-266$.

DeVellis, R. F. (2003). Scale development: Theory and applications (2nd ed.). USA: Sage. Dörnyei, Z. (2003). Questionnaires in second language research: Construction, administration, and processing. Mahwah, New Jersey: Lawrence Erlbaum. 
Fantini, A. E. (2007). Exploring and assessing intercultural competence. (CSD Research Paper No. 07-01). St. Louis, MO: Washington University, Center for Social Development.

Fantini, A. E. (2009). Assessing intercultural competence. The SAGE handbook of intercultural competence, 456-476.

Fraenkel, J. R., Wallen, N. E., \& Hyun, H. H. (2012). How to design and evaluate research in education (8th ed.). McGraw-Hill.

Freeman, D. (2002). The hidden side of the work: Teacher knowledge and learning to teach. Language Teaching, 35, 1-13.

Hair, J., Black, W. C., Babin, B. J., \& Anderson, R. E. (2010). Multivariate data analysis (7th ed.). Pearson Education International.

Hammer, M. R., \& Bennett, M. J. (1998). The intercultural development inventory (IDI) manual. Intercultural Communication Institute.

Hammer, M. R., Bennett, M., \& Wiseman, R. (2003). Measuring intercultural sensitivity: The intercultural development inventory. International Journal of Intercultural Relations, 27(4), 421-443.

Kılıç, S. (2013) English lectures' beliefs regarding Intercultural Competence. Hasan Ali Yücel Eğitim Fakültesi Dergisi, 20 (2), 47-59

Milner, H., Flowers, L., Moore, E., Moore, J., \& Flowers, T. (2003). Preservice Teachers' Awareness of Multiculturalism and Diversity. The High School Journal, 87(1), 63-70. Retrieved from http://www.jstor.org/stable/40364315

Mujis, D. (2004). Doing quantitative research in education. Sage.

Pajares, M. F. (1992) Teachers' beliefs and education research: cleaning up a messy construct, Review of Educational Research, 63, 307-332

Richardson, V. (2003). Preservice teachers' beliefs. In: J Raths, AC McAninch (Eds.): Teacher Beliefs and-Classroom Performance: The Impact of Teacher Education. Advances in Teacher Education. Volume 6. Greenwich, CT: Information Age Publishing, pp. 1-22.

Sercu, L., Bandura, E., Castro, P., Davcheva, L., Laskaridou, C., Lundgren, U., Mendez García, M. \& Ryan, P. (2005). Foreign language teachers and intercultural competence: an international investigation. Clevedon: Multilingual Matters.

Sercu, L. (2006). The foreign language and intercultural competence teacher: the acquisition of a new professional identity. Intercultural Education, Vol. 17(1), 55-72

Tavşancıl, E. (2005). Tutumların ölçülmesi ve SPSS ile verilen analizi. Nobel Yayın Dağıtım

Young, T. J., \& Sachdev, I. (2011). Intercultural communicative competence: Exploring English language teachers' beliefs and practices. Language awareness, 20(2), 81-98. 